\title{
ERRATA
}

\section{The effects of stress on brain and adrenal stem cells}

MFR de Celis, SR Bornstein, A Androutsellis-Theotokis, CL Andoniadou, J Licinio, M-L Wong and M Ehrhart-Bornstein

Molecular Psychiatry (2016) 21, 722; doi:10.1038/mp.2016.26; published online 1 March 2016

Correction to: Molecular Psychiatry; advance online publication, 26 January 2016; doi: 10.1038/mp.2015.230
Following publication of the above article, the authors noticed that the first author's name was presented incorrectly. The author's name should have appeared as MF Rubin de Celis. The publisher regrets the error.

\section{Citalopram and sertraline exposure compromises embryonic bone development}

D Fraher, JM Hodge, FM Collier, JS McMillan, RL Kennedy, M Ellis, GC Nicholson, K Walder, S Dodd, M Berk, JA Pasco, LJ Williams and Y Gibert

Molecular Psychiatry (2016) 21, 722; doi:10.1038/mp.2015.155; published online 1 December 2015

Correction to: Molecular Psychiatry (2015); advance online publication 8 September 2015; doi:10.1038/mp.2015.135
The authors LJ Williams and Y Gibert should have been designated as co-senior authors of the paper. The publisher regrets the error. 